Рекомендована д. фрармац. наук, проф. В. В. Трохимчуком

УДК 339.138:615.322(477)(438)

DOI 10.11603/2312-0967.2016.3.6818

\title{
ПОРІВНЯЛЬНІ ДОСЛІДЖЕННЯ АСОРТИМЕНТУ ЛІКАРСЬКИХ ЗАСОБІВ НА ОСНОВІ РОСЛИННОЇ СИРОВИНИ, ПРЕДСТАВЛЕНОГО НА ФАРМАЦЕВТИЧНИХ РИНКАХ УКРАЇНИ ТА ПОЛЬЩІ
}

\author{
(с) А. І. Денис, А. В. Іванова, Т. А. Грошовий \\ ДВНЗ «Тернопільський державний медичний університет імені \\ І. Я. Горбачевського МОЗ України»
}

\begin{abstract}
Резюме: проведено порівняльне вивчення українського та польського фрармацевтичних ринків готових лікарських засобів на основі рослинної сировини. Проаналізовано структуру асортименту досліджуваних препаратів за ATX класифрікацією, країною-виробником, кількістю активних фрармацевтичних інгредієнтів, порядком відпуску і лікарською формою.
\end{abstract}

Ключові слова: маркетингові дослідження, препарати на основі рослинної сировини, фрармацевтичний ринок України та Польщі.

Вступ. У сучасній клінічній медицині роль фрітотерапії як комплементарного методу прогресивно зростає. Це зумовлено, насамперед, незначною токсичністю і біологічною безпечністю для організму більшості рослинних засобів, а також рядом специорічних особливостей їх фрармакологічної активності [1].

В Україні протягом останніх трьох років прийнято ряд програм із розвитку імпортозаміщення лікарських засобів. На даний час чинна програма, яка передбачає, що імпортні лікарські препарати, які присутні на вітчизняному фармацевтичному ринку протягом багатьох років і втратили патентний захист, повинні бути замінені з позиції економічної доцільності вітчизняними препаратами [2]. Опрацьовані джерела літератури показують, що економічна вигода України від продукції in bulk не завжди значима. Звичайно, якоюсь мірою фрармацевтичні компанії економлять енерго- та трудоресурси, пакувальні матеріали, паперові носії, це сприяє зниженню оптово-відпускної ціни на лікарські засоби і, як наслідок, покращує їх доступність для пацієнтів. Водночас це лише частково вирішує питання імпортозаміщення лікарських засобів [3].

Оскільки в Україні достатньо підприємств, які виробляють лікарські засоби на основі рослинної сировини (PC) і достатньо сировинної бази, найбільш ефективним рішенням щодо імпортозаміщення буде виробництво вітчизняних препаратів на основі РС у повному циклі. І досвід Польщі, яка нарощує виробництво рослинних препаратів, може бути цікавим і для українських виробників.

Мета роботи - порівняльне дослідження асортименту вітчизняного та польського ринку готових препаратів на основі РC.
Методи дослідження. Для одержання інорормації використовували Державний реєстр лікарських засобів України [4] та Польщі [5] станом на січень 2016 року. Асортимент лікарських засобів на основі РС аналізували за АТХ класифрікацією, країною-виробником, кількістю активних фрармацевтичних інгредієнтів, порядком відпуску і лікарською формою. У процесі дослідження використовували методи інформаційного пошуку, математико-статистичний, а також узагальнення та аналізу.

Результати й обговорення. Аналіз асортименту лікарських засобів на основі РС за АТХ класифікацією показав, що на ринку Польщі найбільша кількість препаратів за кодом N «Лікарські засоби для лікування захворювань нервової системи» - 37 \% і С «Лікарські засоби для лікування захворювань серцевосудинної системи» - 18 \%, на українському ринку ці показники становлять по 14 \% кожен (рис.1).

Найбільшу частку досліджуваного ринку України займають препарати за кодом А «Лікарські засоби, що впливають на травну систему та обмін речовин» - 25 \% і R «Лікарські засоби для лікування захворювань дихальної системи» - $20 \%$, тоді як на ринку Польщі ці показники становлять лише по $9 \%$ кожен. Також значну частину ринку як Польщі, так і України займають препарати з групи $L$ «Протипухлинні лікарські засоби та імуномодулятори» - 10 і 8 \% відповідно. Варто зазначити, що в Україні присутні препарати групи J «Протимікробні лікарські засоби для системного використання», а на ринку Польщі вони взагалі відсутні.

У результаті дослідження встановлено, що на вітчизняному ринку лікарських засобів на основі РC представлено 39 \% препаратів зарубіжного вироб-

ISSN 2312-0967. Фармацевтичний часопис. 2016. № 3 


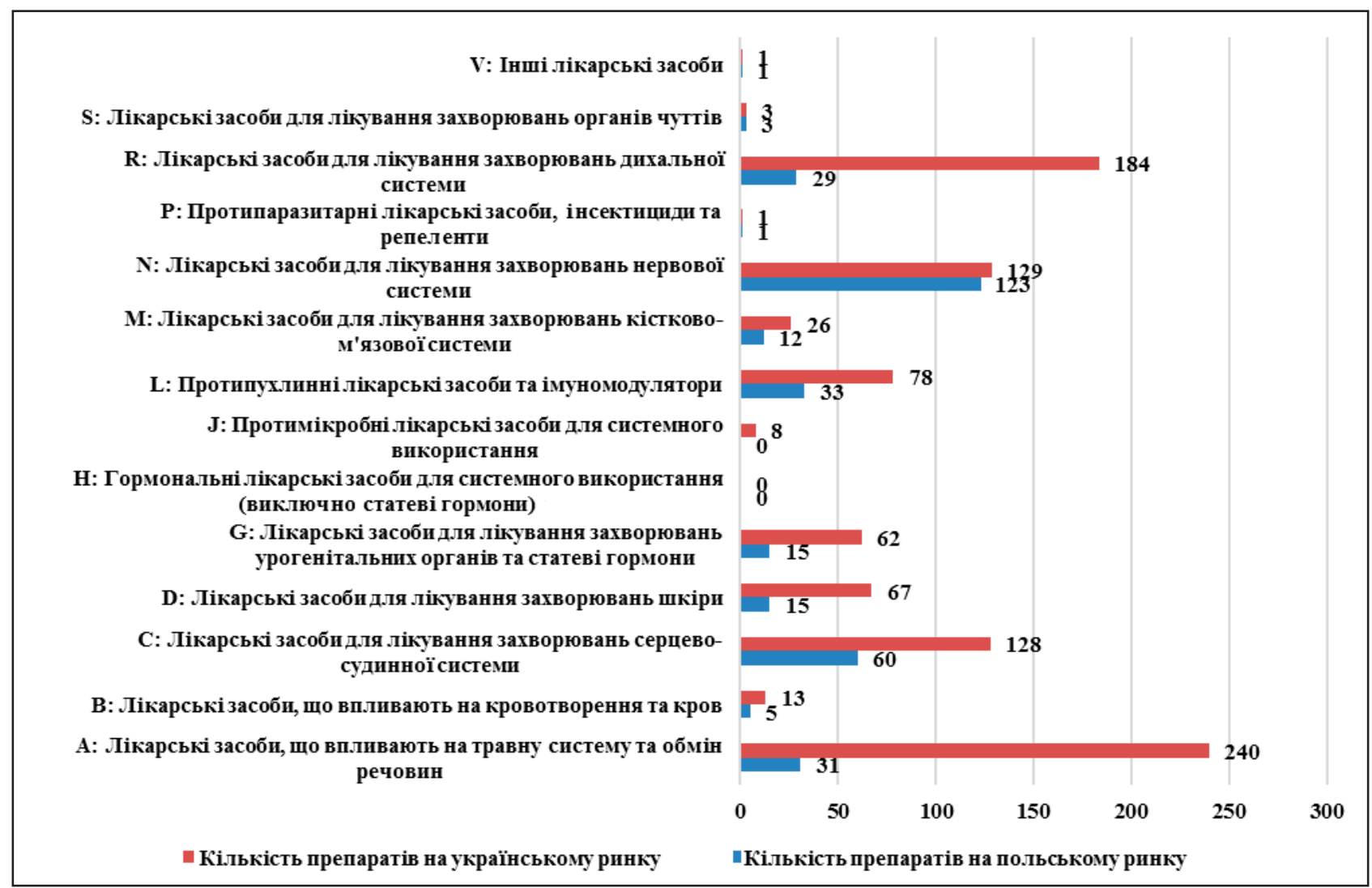

Рис. 1. Розподіл лікарських засобів на основі РС, зареєстрованих на фрармацевтичних ринках України і Польщі за АTХ класифрікацією.

ництва, тоді як на ринку Польщі таких препаратів на $10 \%$ менше. Загалом зарубіжні лікарські засоби на основі РС на фрармацевтичний ринок України постачають 178 фрірм-виробників із 38 країн світу. Перші позиції серед країн-виробників займають Німеччина - $25 \%$, Індія - $14 \%$, Польща - 5 \%, Словенія і Франція - по $4 \%$, Австрія, Чехія, США та Болгарії - по $3 \%$. По 2 \% ринку припадає на 12 країн-виробників (Швейцарія, Іспанія, Угорщина, Австралія, Велика Британія, Італія, Нідерланди, Румунія, Російська Федерація, В'єтнам, Пакистан, Швеція). Ще 17 країн-виробників займають менше 1 \% кожна від загальної частки ринку.

Серед зарубіжних фрірм-виробників лідируючі позиції займають Др. Тайсс Натурварен ГмбХ, Німеччина; Біонорика СЕ, Німеччина; Юніфрарм, Інк, США - кожна по 3 \% (рис. 2).

На фрармацевтичному ринку Польщі зарубіжні препарати на основі РС представлені лише із 11 країнвиробників. Лідируючі позиції займають Німеччина - 29 \%, Швеція - 14 \%, Велика Британія - 12 \%, Чехія - $9 \%$, Австрія і Франція - по $7 \%$. По $5 \%$ ринку припадає на Угорщину і Словенію, 4 \% - на Індію, по 3 \% на Нідерланди і Ісландію. Препарати болгарського і бельгійського виробництва на ринку Польщі займають лише по 1 \% від загальної частки зарубіжних препаратів на основі РС.
Лідируючі позиції з-поміж зарубіжних орірмвиробників на фрармацевтичному ринку Польщі займають McNeil AB, Швеція - 7 \%, KRKA, d.d., Novo mesto, Словенія - 5 \%. По $4 \%$ ринку припадає на Sandoz GmbH, Австрія; Aga Kommerz spol. s.r.o, Чехія; Gedeon Richter Plc., Угорщина і Hospira UK Limited, Велика Британія (рис. 3).

щодо вітчизняних препаратів, то їх частка складає 61 \% від загальної кількості зареєстрованих лікарських засобів на основі РС на фрармацевтичному ринку України, тоді як аналогічна продукція на ринку Польщі займає $71 \%$.

На українському фрармацевтичному ринку наявний широкий спектр вітчизняних фрірм-виробників досліджуваних препаратів. Зокрема, найбільше лікарських засобів на основі РС зареєстрували: ПрАТ «Ліктрави», його частка сновить $12 \%$, ПрАТ Фармацевтична фрабрика «Віола» - $11 \%$, ТОВ «Тернофрарм» - $10 \%$, ПАТ «Лубнифрарм» - 9 \%, ТОВ «Фармацевтична компанія «Здоров'я» - 6 \%, ТОВ «ДКП «Фармацевтична фрабрика» та ПАТ «Фітофрарм» - по 5 \% кожна. Також значну частину ринку займають ПАТ НВЦ «Борщагівський ХФЗ»- 4 \%, ПАТ «Фармак», ПАТ «Галичфрарм», ПАТ «Біолік», Комунальне підприємство «Луганська обласна «Фармація», ПАТ «Хімфрармзавод «Червона зірка» - по 3 \%. По 2 \% вітчизняного фрармацевтичного ринку займає продукція таких виробників, як ТОВ

ISSN 2312-0967. Pharmaceutical review. 2016. № 3 
Фармацевтичний менеджмент, маркетинг та логістика

Pharmaceutical management, marketing and logistics

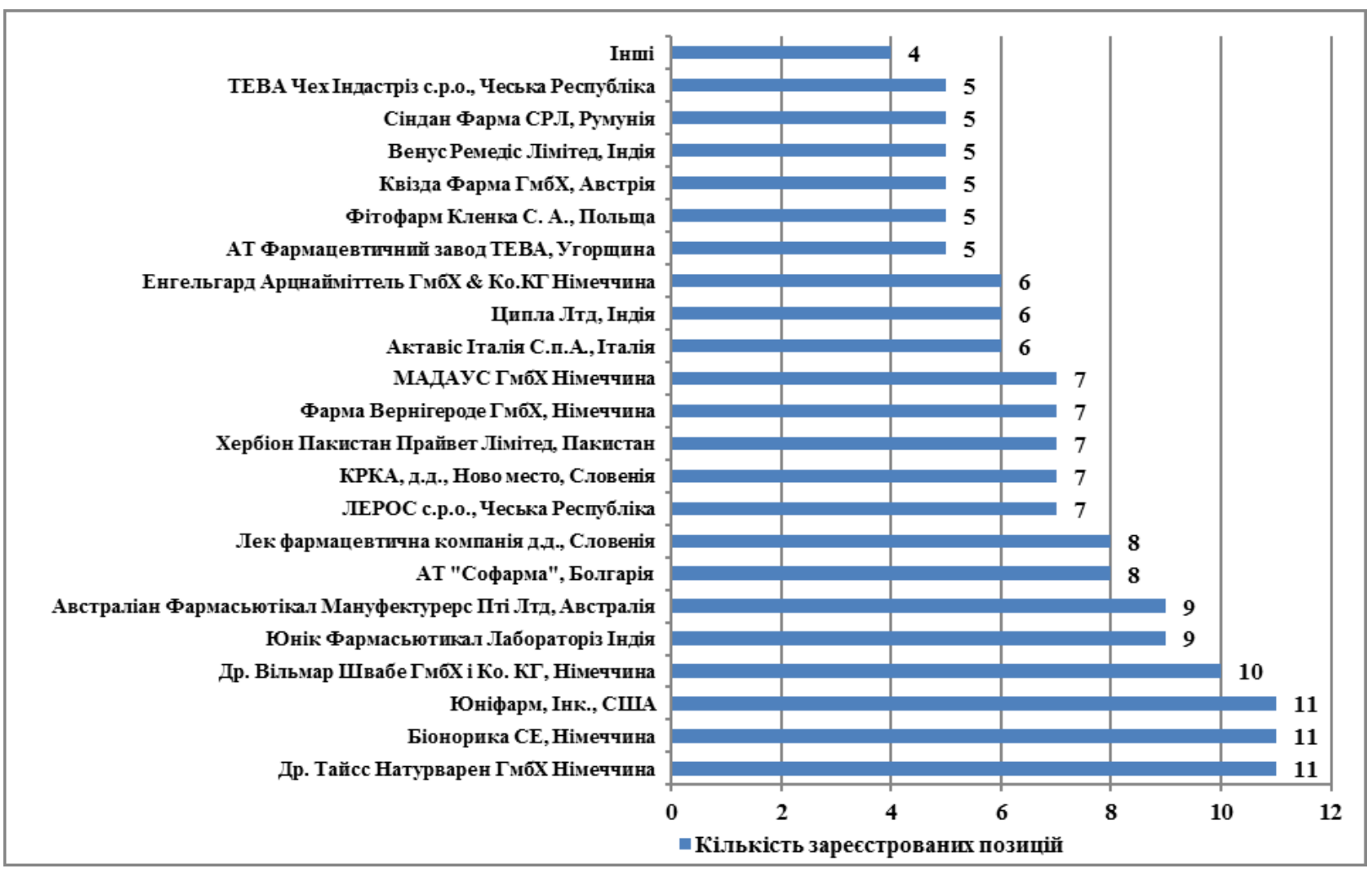

Рис. 2. Розподіл зарубіжних фрірм-виробників лікарських засобів на основі РС на фрармацевтичному ринку України за кількістю зареєстрованих позицій.

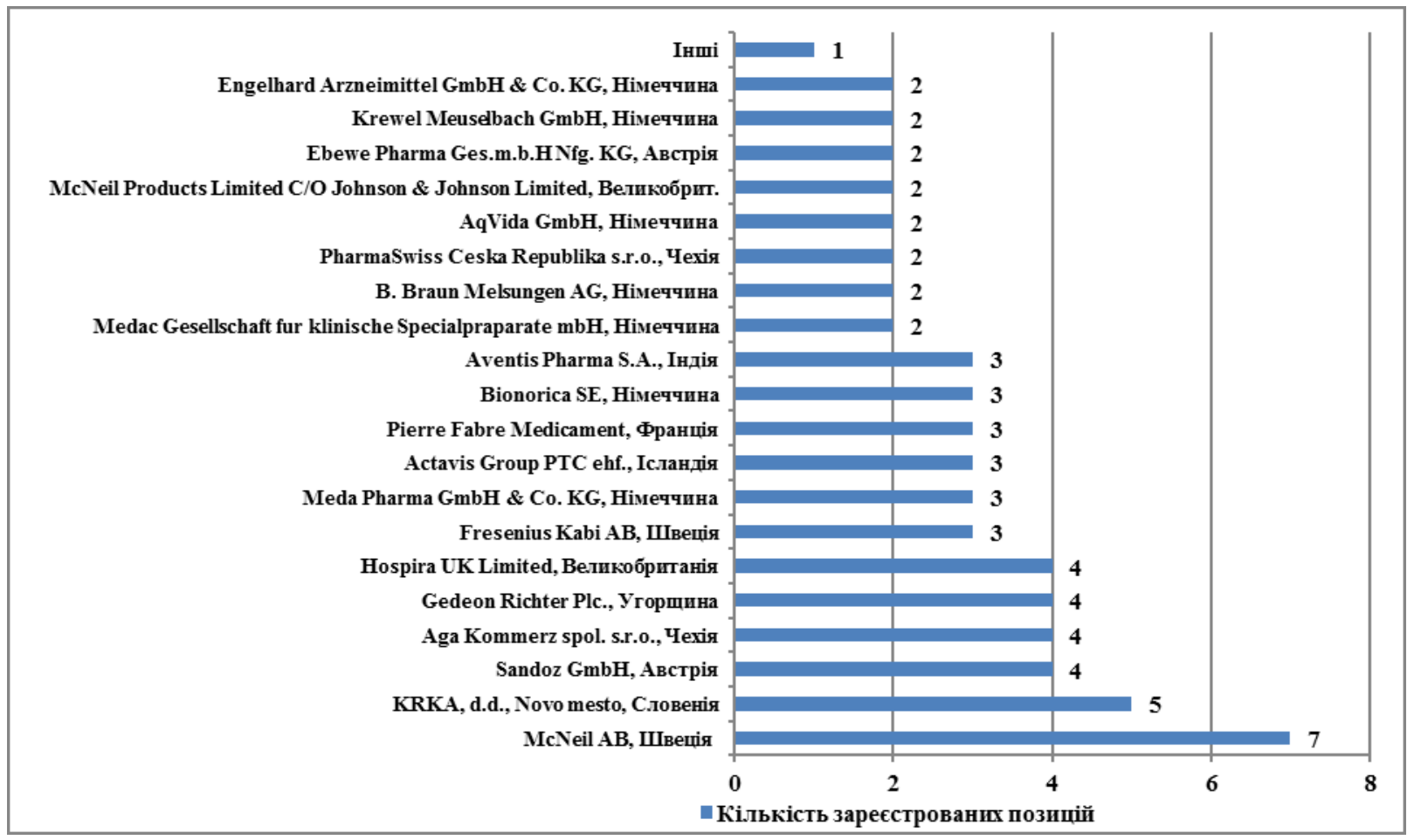

Рис. 3. Розподіл зарубіжних фрірм-виробників лікарських засобів на основі РС на фрармацевтичному ринку Польщі за кількістю зареєстрованих позицій.

ISSN 2312-0967. Фармацевтичний часопис. 2016. № 3 
«Дослідний завод «ГНЦЛС», ПАТ «Київський вітамінний завод», ПАТ «Київмедпрепарат» та ТОВ «Фармекс Груп». Частка препаратів інших виробників на ринку України становить до 1 \% на кожного.

На польському фрармацевтичному ринку значна кількість препаратів на основі РС представлена вітчизняними виробниками. Встановлено, що лідируючі позиції займають Poznańskie Zakłady Zielarskie «Herbapol» S.A - $13 \%$, InPharm Sp. z o.o. - $9 \%$, Delfarma Sp. z о.о. - 7 \%. По 5 \% ринку припадає на Pretium Farm Sp. z o.o., i Przedsiębiorstwo Produkcji Farmaceutycznej HASCO-LEK S.A., а по 4\% - на Aflofarm Farmacja Polska Sp. z o.o., Phytopharm Klęka S.A. та Forfarm Sp. Z OO. Такі фрірми-виробники, як Omega Pharma Poland Sp. z o.o., Biofarm Sp. z o.o., Teva Pharmaceuticals Polska Sp. z o.o., Avrentim Sp. z o.o., PharmaVitae Sp. z o.o. sp. k. займають незначну частку ринку - по 3 \%. Частка препаратів інших виробників на ринку Польщі становить до 2 \% на кожного.

Асортимент лікарських засобів на основі РС, представлений на обох ринках, аналізували і за кількістю активних фрармацевтичних інгредієнтів. Так, на ринку України переважають монопрепарати, їх частка ста- новить 58 \%. Проте на ринку Польщі таких препаратів значно більше - 84 \%. Частка комбінованих препаратів складає лише 42 і 16 \% відповідно.

Щодо порядку відпуску, то в Україні 88 \% проаналізованої вибірки препаратів відпускаються без рецепта, а $12 \%$ - за рецептом лікаря. На польському срармацевтичному ринку $27 \%$ рецептурних і $69 \%$ ОТС-препаратів. Цікаво, що 4 \% лікарських засобів на основі РС, зареєстрованих на польському ринку, використовують виключно в стаціонарних умовах (Vinblastin-Richter, Vinorayne, ClinOleic $20 \%$, Intralipid $10 \%$, Intralipid $20 \%$, Lipidem, Lipofundin MCT/LCT 10. $20 \%$, Paclitaxel Hospira, Paclitaxelum Accord, Paclitaxelum TEVA, Sindaxel, Docetaxel Hospira, Docetaxel Pfizer).

Також проаналізовано лікарські засоби на основі РC за фрормою випуску. На українському фармацевтичному ринку досліджувані препарати найчастіше присутні у формі таблеток - 20 \% і лікарської рослинної сировини (ЛРС) - 14 \% (рис. 4), а на ринку Польщі лише таблетовані лікарські фрорми мають суттєву перевагу, їх частка становить 35 \%. На польському ринку (рис. 5) присутня невелика кількість препаратів у вигляді ЛРС і зовсім відсутні препарати у вигляді

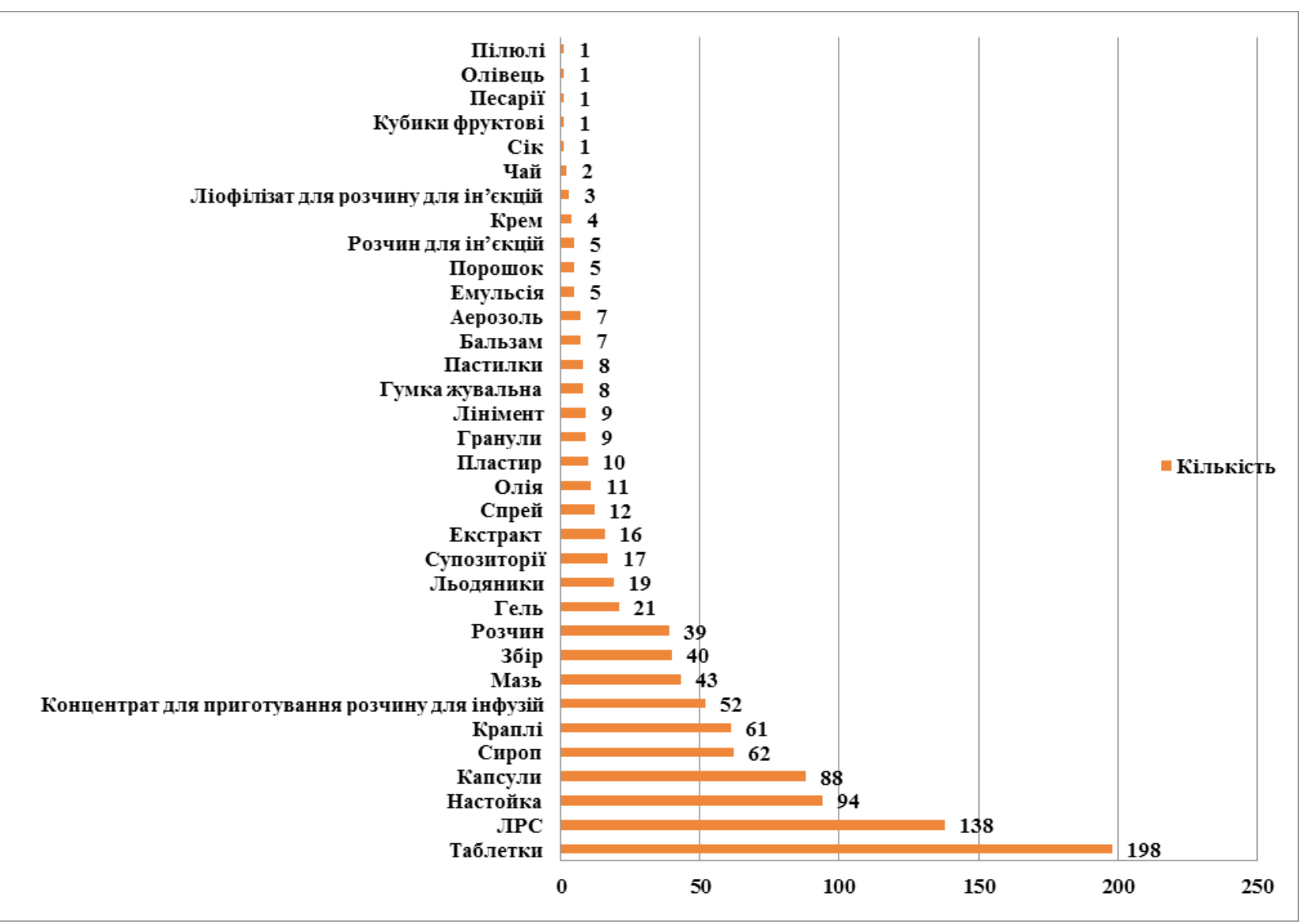

Рис. 4. Розподіл лікарських засобів на основі РС, зареєстрованих на фрармацевтичному ринку України за фрормою випуску.

ISSN 2312-0967. Pharmaceutical review. 2016. № 3 
Фармацевтичний менеджмент, маркетинг та логістика

Pharmaceutical management, marketing and logistics

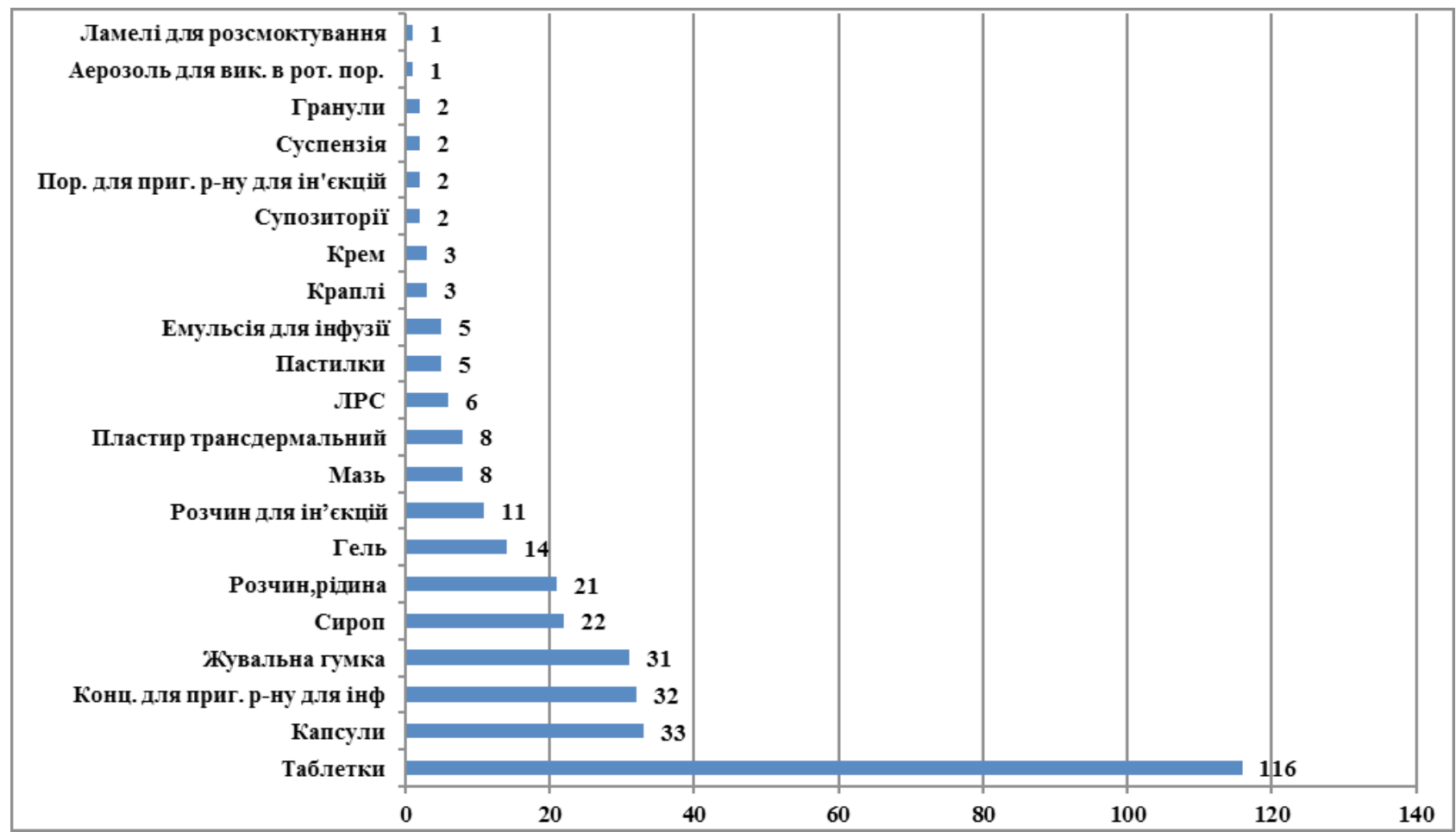

Рис. 5. Розподіл лікарських засобів на основі РС, зареєстрованих на фрармацевтичному ринку Польщі за фрормою випуску.

настойок, тоді як на ринку України частка цих препаратів є досить високою.

Загалом на вітчизняному фармацевтичному ринку спостерігається більше різноманіття лікарських форм. Наприклад, олівці, пілюлі, песарії, кубики фрруктові, сік - хоч і незначно, але таки представлені на ринку України, а у Польщі - відсутні. Натомість у Польщі є ламелі для розсмоктування, проте в Україні лікарських засобів у такій фрормі випуску немає.

Висновки. Проведено порівняльне вивчення лікарських засобів на основі РС, що представлені на фрармацевтичних ринках України та Польщі. Асортимент лікарських засобів проаналізували за країною-виробником, кількістю активних фрармацевтичних інгредієнтів, порядком відпуску, лікарською фрормою і АТХ класифрікацією.

\section{Список літератури}

1. Макух Х. І. Клініко-фрармацевтичне обґрунтування моделі раціональної фрітотерапії в охороні здоров'я України: автореф. дис. на здобуття наук. ступеня канд. фарм. наук: спец. 15:00:01 - Технологія ліків, організація фрармацевтичної справи та судова фрармація / Х. І. Макух. - Львів, 2013. - 24 с.

2. Концепція розвитку фрармацевтичного сектора галузі охорони здоров'я України на 2011 - 2020 роки : наказ МО3 України від 13 вересня 2010 року № 769:

[Електронний ресурс] /: http://moz.gov.ua/ua/portal/ dn_20100913_769.html/

3. Демченко Н. В. Стратегія імпортозаміщення у фармацевтичній галузі: особливості та перспективи реалізації / Н. В. Демченко // Вісник ОНУ імені І. І. Мечникова. - 2014. - Т. 19. - № 2/2. - С. 56-60.

4. Державний реєстр лікарських засобів: [Електронний pecypc] /: http://www.drlz.kiev.ua/

5. Rejestr Produktów Leczniczych: [Електронний ресурс] I: https://www.rejestrymedyczne.csioz.gov.pl/ 
Фармацевтичний менеджмент, маркетинг та логістика

Pharmaceutical management, marketing and logistics

СРАВНИТЕЛЬНОЕ ИССЛЕДОВАНИЕ АССОРТИМЕНТА ЛЕКАРСТВЕННЫХ СРЕДСТВ НА ОСНОВЕ РАСТИТЕЛЬНОГО СЫРЬЯ, ПРЕДСТАВЛЕННОГО НА ФАРМАЦЕВТИЧЕСКОМ РЫНКЕ УКРАИНЫ И польши

\section{А. И. Денис, А. В. Иванова, Т. А. Грошовый}

гвУз «Тернопольский государственный медицинский университет имени И. Я. Горбачевского Мз Украины»

Резюме: проведено сравнительное изучение украинского и польского фрармацевтических рынков готовых лекарственных средств на основе растительного сырья. Проанализирована структура ассортимента исследуемых препаратов за страной-производителем, количеством активных фрармацевтических ингредиентов, порядком отпуска, лекарственной фрормой и АТХ классификацией.

Ключевые слова: маркетинговые исследования, препараты на основе растительного сырья, фрармацевтический рынок Украины и Польши.

\section{COMPARATIVE STUDY OF ASSORTMENT OF DRUGS BASED ON HERBAL RAW MATERIAL REPRESENTED AT PHARMACEUTICAL MARKET OF UKRAINE AND POLAND}

\section{A. I. Denys, A. V. Ivanova, T. A. Hroshovyi}

I. Horbachevsky Ternopil State Medical University

Summary: a comparative study of the Ukrainian and Polish pharmaceutical markets of finished medicinal products based on herbal raw material has been conducted. The structure of the assortment of preparations under study has been analyzed according to the manufacturing country, dosage form, pharmacotherapeutic group and order of dispensing.

Key words: marketing research, preparations based on herbal raw material, pharmaceutical market of Ukraine and Poland.

Отримано 20.07.2016

ISSN 2312-0967. Pharmaceutical review. 2016. № 3 